P-ISSN: 2615-1723

E-ISSN: 2615-1766 April 2020
Jurnal Riset Pendidikan Dasar

03 (1), (2020) 25-33

Submitted: Januari, Accepted Februari, Published: April

\title{
KEEFEKTIFAN MODEL PEMBELAJARAN CHILDREN LEARNING IN SCIENCE (CLIS) DENGAN PROBLEM BASEDLEARNING (PBL) TERHADA KEMAMPUAN BERPIKIR KRITIS PEMBELAJARAN TEMATIK KELAS 5
}

\author{
Moh Rifai $^{{ }^{*}}$, Tego Prasetyo ${ }^{2}$ \\ ${ }^{1,2}$ Program Studi Pendidikan Guru Sekolah Dasar, Fakultas Keguruan dan Ilmu Pendidkan, \\ Universitas Kristen Satya Wacana Salatiga, Indonesia
}

Korenspondensi *E-mai1:292016027@student.uksw.edu

\begin{abstract}
Abstrak
Penelitian ini bertujuan untuk mengetahui adanya keefektifan model Children Learning in Sciencedengan modelProblem Based Learningterhadap kemampuan berpikir kritis siswa kelas 5. Jenis penelitian yang digunakan adalah penelitian eksperimen dengan desain penelitian Non-aquivalent Control Grup Design. Penelitian ini dilakukan pada siswa kelas 5 SD Negeri Ngombak 1 sebagai kelas (eksperimen 1) dan SD N Ngombak 2 sebagai kelas (eksperimen 2). Teknik pengembilan data menggunakan instrumen angket sebanyak 20 pernyataan. Uji normalitas data dilakukan untuk mengetahui normalitas data pada kelas kontrol, kelas (eksperimen 1) dan kelas (eksperimen 2) dengan masing-masing sebesar Sig. $0.200>0.05$ maka dapat dikatakan ketiga kelas tersebut berdistribusi normal. Uji Homogenitas (One-way Anova) menunjukan hasil pada kelas eksperimen 1 sebesar Sig.0.385> 0.05 dan kelas eksperimen 2 sebesar Sig 0,435> 0.05 maka kedua kelas tersebut bersifat homogen. Teknik analisis data menggunakan Uji $\mathrm{t}$ (independent sample t-test) dengan taraf Sig. 0.05. Hasil penelitian menunjukan terdapat pengaruh penggunaan model PBL dan CLIS terhadap berpikir kritis siswa kelas 5 yang ditunjukan hasil Sig. (2-taied) $0.002<0.05$ maka $\mathrm{H}_{0}$ ditolak dan $\mathrm{H}_{\mathrm{a}}$ diterima,sehingga dapatdisimpulkan bahwa model PBL lebih efektif dibandingkan model CLIS terhadap berpikir kritis siswa kelas 5 .
\end{abstract}

Kata Kunci: Model Children Learning in Science (CLIS), Model Problem BasedLearning (PBL), Berpikir Kritis

\section{THE EFFECTIVENESS OF CHILDREN LEARNING IN SCIENCE (CLIS) LEARNING MODEL WITH PROBLE BASED LEARNING (PBL) ON CRITICAL THINKING SKILL THEMATIC LEARNING GRADE 5 \\ Abstract}

The purpose of this research is to know about effectiveness children learning in science model with problem based learning model to the critical thinking skills of 5th grade students.the type this research is experimental with Nonaquivalent control group design. The research was conducted on 5th grade students ngombak 1 elementary school as experimental class 1 and ngombak 2 as experimental class 2. Data techniques use questionnare instrument with 20 questions. Normality data test to know about normality of data in control class, experiment class 1 and experiment class 2 are Sign 0,200>0,05 so that can be said that all three classes are normally distributed. Homogenity test (oneway anova) shows the results of experimental class 1 of Sig.0,385>0,05 and the experimental class 2 of Sig 0,435>0,05 then both classes are homogeneous. Analysis data technique use T-Test (independent sample T-Test) with level asig 0,05. The results this research is have effect of using PBL model and CLIS model on 5th grade students' critical thinking show sig.(2-tailed) 0,002<0,05 the. Ho is rejected and Ha is accepted, so it can be concluded that PBL model is more effective than CLIS model for critical thinking students

Keywords:Model Children Learning in Science (CLIS), Model Problem Based Learning (PBL),Critical Thinking

Copyright C2020, JRPD, ISSN 2615 - 1723 (Print), ISSN 2615 - 1766 (Online) 


\section{PENDAHULUAN}

Pendidikan di Indonesia berada pada posisi ke 62 dari 70 negara peserta Programme for International Student Assessment (PISA) (Setiawan, 2018: 7). Berdasarkan data (PISA) menunjukan mutu pendidikan di Indonesia masih sangat rendah. Upaya meningkatan mutu pendidikan di Indonesia dapat diwujudkan melalui peningkatan kualitas sumber daya manusia (Widodo, 2015:194). Pemerintah telah melakukan upaya meningkatan kualitassumber daya manusianya melalui pendidikan yaitu dengan menerapkan kurikulum 2013.

Kurikulum 2013 menuntut siswa memiliki kemampuan 4C (Critical Thinking, Communiaction, Collaboration, Creativity). Kemampuan 4C sangat dibutuhkan pada saat abad 21 terutama kemampuan berpikir kritis (Critical Thinking). Menurut Zubaidah (2016) Kemampuan berpikir kritis menggambarkan kemampuan untuk menganalisis, memeriksa, menafsirkan, dan mengevaluasi bukti. Kemampuan berpikir kritis sangatlah penting dimiliki siswa agar kelak siswa dapat memahami realita kehidupan dan dapat memecahkan setiap permasalah untuk mendapatkan keputusan (Rosana, 2014: 37). Tuntutan siswa untuk mempunyai kemampuan berpikir kritis didukung oleh pembelajaran tematik yang diterapkan dalam Kurikulum.

Pembelajaran tematik yang memadukan materi dari beberapa muatan pelajaran ke dalam satu tema menjadikan pembelajaran lebih bermakna (Astutik, 2016: 351). Hal tersebut dapat membantu mengembangkan kemampuan berpikir kritis siswa. Dengan adanya paduan materi dari beberapa muatan pelajaran, siswa akan belajar secara mendalam dan menyeluruh. Pembelajaran tematik dapat menyajikan permasalahan sehari-hari sehingga siswa dapat mengembangkan kemampuan berpikir kritis untuk memecahkan Copyright $(2020$, JRPD, ISSN 2615 - 1723 (Print), ISSN 2615 - 1766 (Online)

permasalahan dengan tepat dan dengan berbagai alternatif penyelesaian, akan tetapi kondisi di sekolah kemampuan berpikir kritis siswa belum dilatih dengan maksimal.

pembelajaran berbasis pemecahan masalah untuk mengembangkan kemampuan berpikir kritis siswa. Menurut Rohmatin (2014:3) pemecahan masalah memungkinkan mampu mengajarkan peserta didik tentang berpikir kritis dan dapat mengetahui mengetahui kemampuan peserta didik. Adanya model berbasis masalah yang diterapkan dapat meningkatkan daya berfikir kritis, sistematis, logis, dan kreatif dalam menghadapi masalah dalam lingkungannya sehari-hari. Dengan demikian kemapuan berpikir kritis dapat membantu peserta didik di masa mendatang dalam menghadapi permasalahan. Hal ini dikarenakan selama duduk di bangku pendidikan sudah terbiasa memecahkan permasalahan dalam kehidupan sehari-hari.

Hasil observasi dan wawancara yang dilakukan di SD Negeri Ngombak pada kelas 5, pembelajaran di sekolah tersebut belum melatih kemampuan berpikir kritis siswanya dengan maksimal. Pembelajaran hanya menekankan pada hafalan konsep. Guru belum menemukan dan memahami model yang dapat melatih kemampuan berpikir kritis peserta didik. Purwati (2016: 86) berpendapat bahwa berpikir kritis merupakan suatu kemampuan untuk menganalisis dan mengevaluasi informasi yang telah didapatkan dari hasil pengamatan, penalaran pengalaman, maupun komunikasi untuk mengambil keputusan apakah informasi tersebut dapat dipercaya sehingga dapat memberikan kesimpulan yang rasional dan benar.

Menurut Faiz (2012) terdapat beberapa kriteria atau ciri-ciri orang dapat dikatakan mempunyai kemampuan berpikir kritis antara lain: 1) memakai kalimat fakta-fakta yang tepat dan jujur, 2) membangun pemikiran serta

$$
\text { Guru dapat menerapkan model }
$$


pengungkapkan isi pikiran secara logis atau (masuk akal) dan jelas, 3) dapat membedakan antara kesimpulan yang didasarkan atas logika yang valid dengan logika yang tidak valid, 4) mampu mengidentifikasi kecukupan data, 5) menyangkal atau menyanggah suatu pendapat yang tidak relevan dan menyampaikan pendapat yang sesuai, 6) mengkaji kembali suatu pandangan dan menanyakan implikasi dari suatu sudut pandang, 7) menyadari adanyapemahaman serta fakta seseorang selalu terbatas, 8) mengenali kemungkinan kekeliruan suatu argumen dan kemungkinan bisa dalam berargumen.

Pembelajaran dan gaya belajar yang diimplementasikan pada peserta didik dapat berpengaruh terhadap kemampuan berpikir kritis peserta didik. Model yang diterapakan ketika proses pembelajaran haruslah pembelajaran yang melibatkan interaksi antara guru dan peserta didik, serta menciptakan suasana yang menyenangkan agar pembelajaran dapat diterima dengan baik dan bermakna. Selain itu model yang digunakan dalam pembelajaran harus memberikan kesempatan peserta didik untuk berlatih memecahkan permasalahan dalam kehidupan sehari-hari sehingga kemempuan berpikir kritis dapat meningkat.

Model pembelajaran (CLIS) Children Learning In Science merupakan model yang merlandaskan pembelajaran kontuktivisme. Menurut Wardani (2015:10) melaui model CLIS diharapkan mampu menciptakan pembelajaran yang interaktif dan aktif, serta menimbulkan rasa ingin tahu terhadap konsep yang belum dipahaminya, dan melatih siswa melakukan observasi melalui percobaan serta menekankan kebermaknaan pembelajaran. Sementara model pembelajaran (PBL) Problem Based Learning merupakan model pembelajaran berbasis masalah, menurut Nugraheni (2016:7) dimana peserta didik mengembangkan keterampilan menyelesaikan

berfikir, keterampilan masalah, menyusun pengetahuan mereka sendiri. Adanya kegiatan penyelidikan yang ada pada model diharapkan peserta didik mampumenjadi lebih paham dengan materi yang diajarkan

Menurut Fajrian (2017: 11) langkahlangkah model CLIS antara lain: 1.Tahapan Orientasi (Orientation), 2) Tahapan pemunculan ide atau gagasan (Restructuring of Ideas), 2. Tahap menyusun kembali ide atau gagasan (Restructuring of Ideas), 3. Tahap pengaplikasian atau penerapan gagasan (Application of Ideas), 4. Tahap pemantapan ide atau gagasan (Review Change in Ideas)

Sedangkan sintak model (PBL) Problem Based Learning Menurut Sari (2012: 16) sintaks model PBL adalah sebagai berikut: 1 . Memberikan orientasi tentang permasalahan kepada peserta didik, 2. Mengorganisasikan peserta didik untuk menemukan penyelesaian masalah, 3. Peserta didik aktif mengumpulkan serta menentukan informasi ataupun data yang berhubungan dengan masalah yang telah dirumuskan, 4. Peserta didik lebih rajin berdiskusi dengan kelompoknya untuk menjawab permasalahan berdasarkan data yang diperoleh.

Penelitian ini bertujuan guna mengetahui adakah terdapat "Keefektifan Model Pembelajaran Children Learning In Science dengan Problem BasedLearning Terhadap Kemampuan Berpikir Kritis Pembelajaran Tematik Kelas 5 SD Gugus Diponegoro Kedungjati Semester II Tahun Pelajaran 2019/2020"

\section{METODE}

Penelitian ini merupakan Penelitian Eksperimen, yaitu metode penelitian yang diterapkan guna menemukan pengaruh perlakuan tertentu terhadap yang lain dalam kondisi yang terkendalikan. Serta jenis 
penelitian ini adalah Penelitian ekperimen semu ( Non-aquivalent Control Grup Design) yang bertujuan untuk mengetahui pengaruh sebab dan akibat dengan menggunakan kelompok kontrol dan kelompok ekperimen, tetapi pemilihan kelompok tidak berdasarkan teknik random.

\section{Desain Eksperimen}

\begin{tabular}{ccc}
\hline $\mathrm{O} 1$ & $\mathrm{X} 1$ & $\mathrm{O} 2$ \\
$\mathrm{O} 3$ & $\mathrm{X} 2$ & $\mathrm{O} 4$ \\
\hline
\end{tabular}

Gambar 1.Desain Eksperimen ( Non-Aquivalent Control Grup Design)

Keterangan :

O1 : Pre-test Kelompok Eksperimen sebelum diberikan perlakuan

O2 : Pos-test Kelompok Eksperimen sesudah diberikan perlakuan

X1 : Perlakuan Model PBL Kelompok Eksperimen 1

-... : Petunjuk bahwa kelas yang diteliti apadanya (intact grup)

O3 : Pre-test Kelompok Eksperimen sebelum diberikan perlakuan

O4 : Pos-test Kelompok Eksperimen sesudah diberikan perlakuan

X2 : Perlakuan Model CLIS Kelompok Ekperimen 2

Populasi dalam penelitian ini adalah siswa SD Negeri Ngombak 1 dan SD Negeri Ngombak 2 Gugus Diponegoro Kedungjati, Grobogan. Sempel penelitian ini seluruh siswa kelas 5 SD Negeri Ngombak 1 sebanyak 21 siswa dan siswa kelas 5 SD Negeri Ngombak 2 sebanyak 26 siswa. Pada penelitian ini terdapat dua variabeldiantaranya variabel bebas dan variabel terikat. Variabel bebas terdari dari Model pembelajaran (PBL) sebagai $\left(\mathrm{X}_{1}\right)$ dan model pembelajaran (CLIS) sebagai $\left(\mathrm{X}_{2}\right)$. Sedangkan variabel terikatnya adalah Kemampuan Berpikir Kritis atau (Y) siswa kelas 5.

Copyright C2020, JRPD, ISSN 2615 - 1723 (Print), ISSN 2615 - 1766 (Online)
Pengukuran kemampuan berpikir kritis siswa menggunakan instrumen pengumpulan data menggunakan angket. Terdapat 20 pernyataan dalam angket berfikir kritis, yang isinya pernyaataan positif dan pernyataan negatif yang dikembangkan berdasarkan indikator berpikir kritis menurut pendapat Fisher. Aspek kemampuan berpikir kritis yang diterapkan pada penelitian ini yaitu : 1) mengidentifikasi masalah, 2) mencari atau mengumpulkan informasi relevan dari bermacam sumber, 3) menyusun atau merangkai berbagai alternatif (jawaban) pemecahan masalah, dan 4) membuat kesimpulan. Setiap pernyataan dalam angket dijawab dengan acuan skala likert dengan pilihan jawaban tidak pernah, jarang, sering, dan sangat sering.

Implementasi RPP dilakukan dengan menerapkan model (PBL) pada proses pembelajaran di kelas (eksperimen 1), dan penerapan model pembelajaran (CLIS) di kelas (eksperimen 2) sedangkan kelas (kontrol) menggunakan pembelajaran konvensional. Terdapat $3 \mathrm{KD}$ yang termuat dalam Tema 7: Peristiwa dalam Kehidupan, Subtema 2, Pembelajaran 5, yaitu KD 3.5 Menggali informasi penting dari teks narasi sejarah yang disajikan secara lisan dan tertulis menggunakan aspek: apa, kapan, siapa, mengepa, dan bagaimana (B. Indonesia), KD 3.7 Menganalisis pengaruh kalor terhadap perubahan suhu dan wujud benda dalam kehidupan sehari-hari (IPA), dan KD 3.3 Memahami tangga nada (SDdP). Proses pembelajaran mengacu pada kerangka berpikir sebagai berikut: 


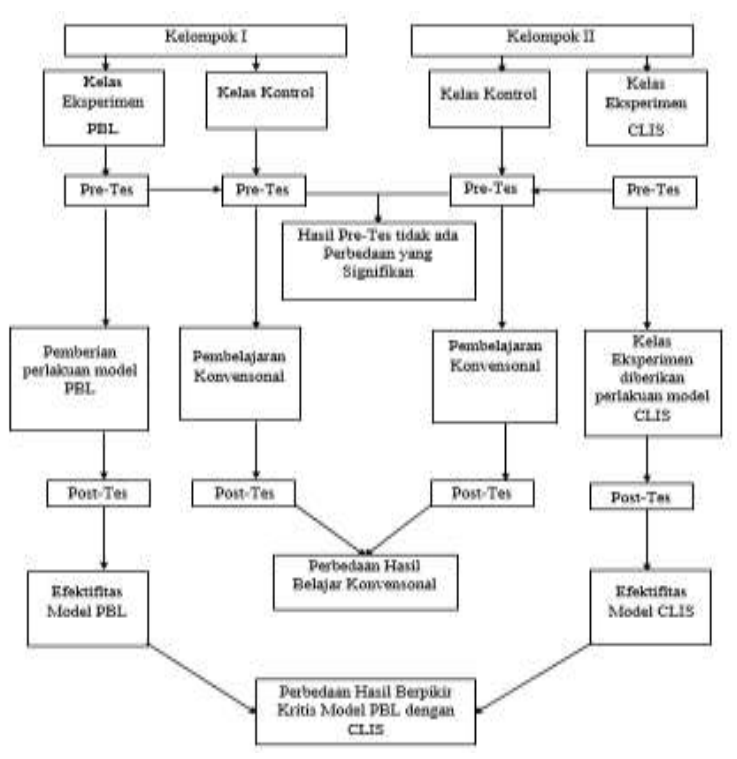

Gambar 2.Kerangka Berpikir Penelitian

Berdasarkan Gambar 2 dapat diketahui bahwa langkah-langkah dalam penelitian dilakukan pada 2 kelompok yaitu kelas (eksperimen) dan kelas (kontrol). Tahapan pertama pemberian pre-tes yang dilakukan pada kelas kontrol dan kelas eksperimen untuk mengetahi hasil pre-tes tidak ada perbedaan yang signifikan. Pada kelas ekperimen diberikan perlakuan model PBL dan model CLIS sedangkan pada kelas (kontrol) masih menggunakan pembelajaran konvensional, kemudian diberikan Pos-tes untuk mengetahui keefektifan model PBL dangan model CLIS.

Teknik analisis data yang digunakan dalam penelitian ini adalah teknik analisis data dengan Uji $t$ (independent sample t-test). Penggunaan uji (independent sample t-test) adalah untuk menjawab hipotesis penelitian yaitu mengetahui adanya keefektifan model terhadap kemampuan berpikir kritis siswa kelas 5 .

\section{HASIL DAN PEMBAHASAN}

Hasil penelitian kemampuan berpikir kritis pada pembelajaran tematik kelas $5 \mathrm{SD}$ dilakukan dengan pemberinan pre-test dan posttest yang digunakan untuk mengukur hasil

Copyright $@ 2020$, JRPD, ISSN 2615 - 1723 (Print), ISSN 2615 - 1766 (Online) belajar kognitif, sedangkan untuk mengukur berpikir kritis diberikan angket pada akhir pembelajaran pada masing-masing kelas. Penelitian ini berfokus pada kemampuan berpikir kritis pembelajaran tematik menggunakan model Problem Based Learning yang dilakukan di kelas (eksperimen 1) dan model Children Learning in Science pada kelas (eksperimen 2). Berikut adalah tabel frekuensi skor hasil berfikir kritis di kelas (eksperimen 1) yang dapat dilihat gambar 3 histogram.

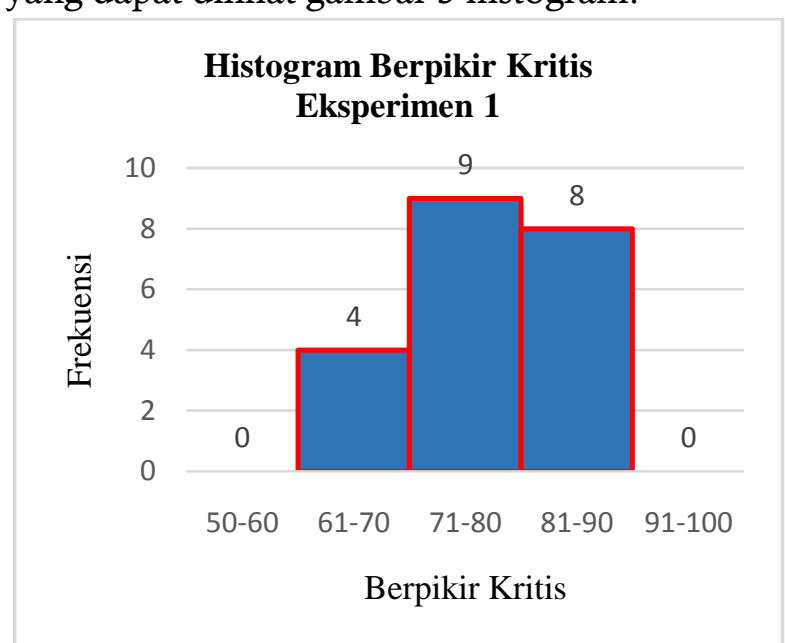

\section{Gambar3.Histogram Berpikir Kritis Kelas (Eksperimen 1)}

Berdasarkan tabel diatas dapat dilihat bahwa skor kemampuan berpikir kritis di kelas eksperimen 1 dengan banyak siswa yang mendapat skor 61 sampai 70 terdiri 4 siswa dengan persentase $19,0 \%$, siswa yang mendapat skor 71 sampai dengan 80 terdiri dari 9 siswa dengan persentase $42,9 \%$, siswa yang mendapat skor 81 sampai dengan 90 terdiri dari 8 siswa dengan persentase $38,1 \%$ serta nilai rata-rata kelas sebesar 77,71.

Berikut data penelitian berpikir kritis pembelajaran tematik dengan menggunakan model (CLIS)yang dilakukan di kelas (eksperimen 2). Berikut adalah tabel frekuensi skor hasil berfikir kritis di kelas (eksperimen 2) yang dapat dilihat padagambar 4 histogram. 


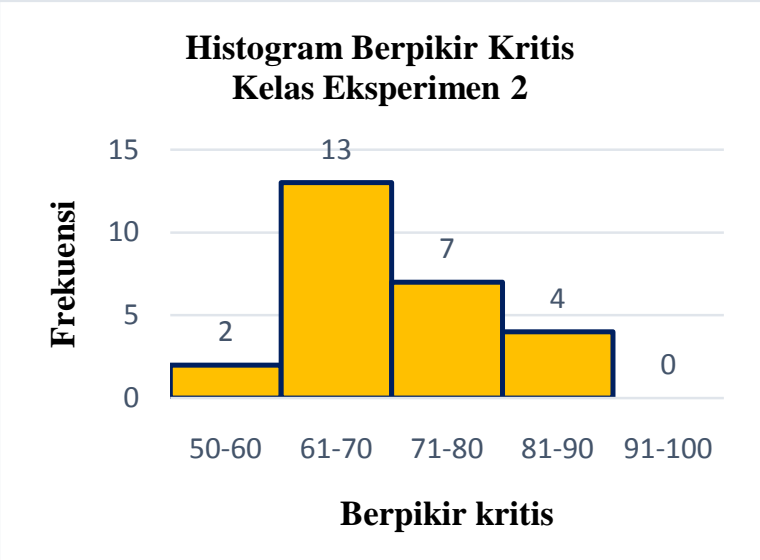

Gambar 4. Histogram Berpikir Kritis Kelas(Eksperimen 2)

Berdasarkan gambar 4 diatas dapat dilihat bahwa skor kemampuan berpikir kritis di kelas eksperimen 2 dengan banyak siswa yang mendapat skor 50 sampai 60 terdiri dari 2 siswa dengan persentase $7,7 \%$, siswa yang mendapat skor 61 sampai dengan 70 terdiri dari 13 siswa dengan persentase $50,0 \%$, siswa yang mendapat skor 71 sampai dengan 80 terdiri dari 7 siswa dengan persentase $15,3 \%$ serta rata-rata kelas sebesar 70,27.

Teknik analisis data dengan uji (independent sample t-test)yang digunakan untuk menguji hipotesis sebagai berikut:

Tabel 1. Uji Normalitas (Kelas Kontrol), Kelas (Eksperimen 1), dan (Kelas Eksperimen 2)

\begin{tabular}{|c|c|c|c|c|}
\hline \multicolumn{5}{|c|}{ One-Sample Kolmogorov-Smirnov Test } \\
\hline & & & Kelas & Kelas \\
\hline & & Kelas Kontrol & $\begin{array}{c}\text { Eksperi-men } \\
1\end{array}$ & $\begin{array}{c}\text { Eksperi- } \\
\text { men } 2\end{array}$ \\
\hline \multicolumn{2}{|l|}{$\mathrm{N}$} & 30 & 21 & 26 \\
\hline \multirow{2}{*}{ Normal Parameters ${ }^{\mathrm{a}, \mathrm{b}}$} & Mean & 78,87 & 77,71 & 70,27 \\
\hline & Std. Deviation & 9,198 & 8,385 & 7,220 \\
\hline \multirow{3}{*}{ Most Extreme Differences } & Absolute & 0,106 & 0,131 & 0,092 \\
\hline & Positive & 0,062 & 0,089 & 0,092 \\
\hline & Negative & $-0,106$ & $-0,131$ & $-0,085$ \\
\hline \multicolumn{2}{|c|}{ Test Statistic } & 0,106 & 0,131 & 0,092 \\
\hline \multicolumn{2}{|c|}{ Asymp. Sig. (2-tailed) } & $.200^{c, d}$ & $.200^{\mathrm{c}, \mathrm{d}}$ & $.200^{c, d}$ \\
\hline
\end{tabular}

Berdasarkan output di atas diketahui (kontrol), kelas (eksperimen 1), dan kelas nilai signifikansi (Sig.) berpikir kritis kelas (eksperimen 2) sebesar 0.200 atau lebih besar Copyright (C2020, JRPD, ISSN 2615 - 1723 (Print), ISSN 2615 - 1766 (Online) 
dari 0.05, maka dapat disimpulkan bahwa kelas kelas kontrol, kelas (eksperimen 1), dan kelas (eksperimen 2) berdistribusi normal. Dasar yang digunakan untuk uji homogenitas adalah sebagai berikut: 1) Jika nilai signifikansi $<0,05$ maka dapat dikatakan bahwa data tidak sama atau heterogen, 2) Jika nilai signifikansi $>0,05$ maka dapat dikatakan bahwa data adalah sama atau homogen.

Data yang diperoleh juga harus bersifat homogen sehingga dapat diketahui bahwa terdapat persamaan antar dua varians. Uji Homogenitas menggunakan rumus One-Way Anova, dan didapatkan hasil sebagai berikut :

Tabel 2. Uji Homogenitas (One-way Anova) Kelas (Kontrol) dan Kelas (Eksperimen 1)

\begin{tabular}{cccc}
\hline \multicolumn{4}{c}{ Test of Homogeneity of Variances } \\
\hline \multicolumn{4}{c}{ Berpikir Kritis } \\
\hline $\begin{array}{c}\text { Levene } \\
\text { Statistic }\end{array}$ & df1 & df2 & Sig. \\
\hline 0,017 & 1 & 49 & 0,896 \\
\hline
\end{tabular}

Kelas (Kontrol) dan Kelas (Eksperimen 2)

\begin{tabular}{cccc}
\hline \multicolumn{4}{c}{ Test of Homogeneity of Variances } \\
\hline \multicolumn{4}{c}{ Berpikir Kritis } \\
\hline $\begin{array}{c}\text { Levene } \\
\text { Statistic }\end{array}$ & df1 & df2 & Sig. \\
\hline 0,768 & 1 & 54 & 0,385 \\
\hline
\end{tabular}

Kelas (Eksperimen 1) dan Kelas (Eksperimen 2)

\begin{tabular}{cccc}
\hline \multicolumn{4}{c}{ Test of Homogeneity of Variances } \\
\hline \multicolumn{4}{c}{ Berpikir Kritis } \\
\hline $\begin{array}{c}\text { Levene } \\
\text { Statistic }\end{array}$ & df1 & df2 & Sig. \\
\hline 0,620 & 1 & 45 & 0,435 \\
\hline
\end{tabular}

Berdasarkan tabel 2 diperoleh hasil bahwa data bersifat homogen dengan Sig. $0.896>0.05$, lavene statistic sebesar 0.017 untuk kelas kontrol dan kelas eksperimen 1. Nilai Sig. $0.358>0.05$, lavene statistic sebesar 0.768 untuk kelas kontol dan kelas eksperimen 2. Nilai Sig. $0.435>0.05$,

lavene statistic sebesar 0.620 untuk kelas (eksperimen 1) dan kelas (eksperimen 2).

Data homogen apabila nilai Sig. lebih besar dari 0.05. Maka data yang diperoleh dari kelas (eksperimen 1) dan kelas (eksperimen 2) bersifat homogen dan memenuhi syarat untuk melakukan uji t. Teknik analisis data yang digunakan adalah uji $\mathrm{t}$ (independent sample $t$ test). Teknik analisis data dilakukan terhadap data hasil berpikir kritis kelas (eksperimen 1) dengan model (PBL) dan kelas (eksperimen 2) dengan model (CLIS). Uji (independent sample $t$ test) digunakan untuk menguji hipotesis yang telah dirumuskan di atas. Dasar pengembilan keputusan dalam uji (independent sample t-test) adalah sebagai berikut: 1) jika nilai Sig. (2tailed) $>0.05$, maka Ho diterima dan $\mathrm{Ha}$ ditolak, 2) jika nilai Sig. (2tailed) $<0.05$, maka Ho ditolak dan Ha diterima.

Tabel 3. Grup Stastistik

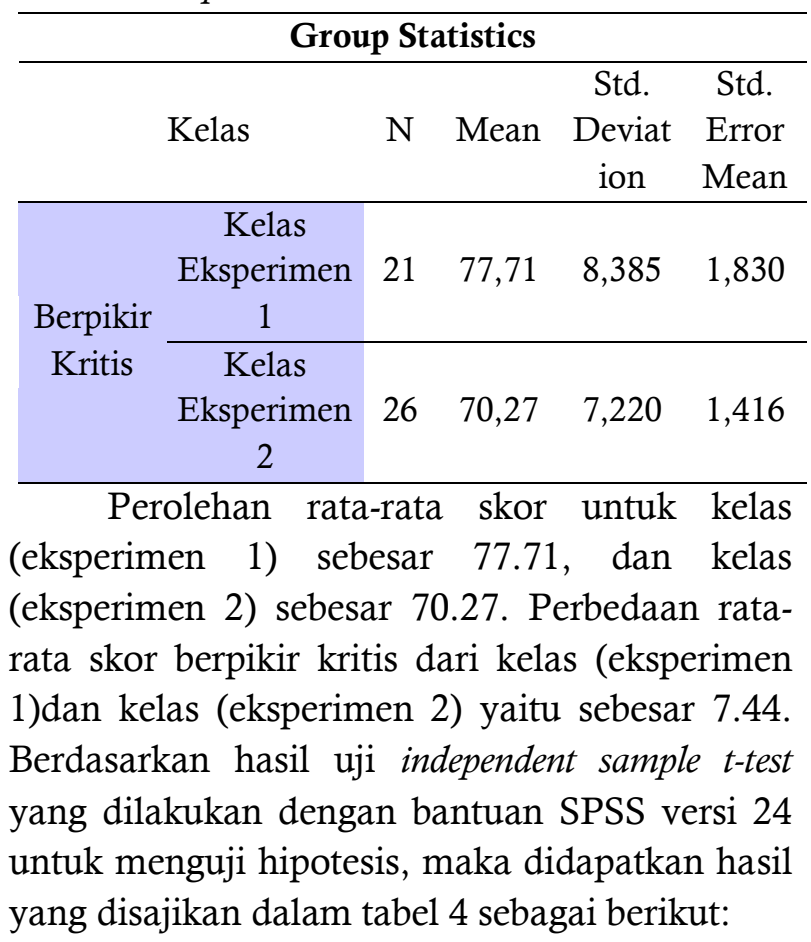

Copyright $@ 2020$, JRPD, ISSN 2615 - 1723 (Print), ISSN 2615 - 1766 (Online) 
Jurnal Riset Pendidikan Dasar, 03 (1), April 2020 (25-33)

Moh Rifai,Tego Prasetyo

Tabel 4. Uji Independent Samples Test

Independent Samples Test

\begin{tabular}{|c|c|c|c|c|c|c|c|c|c|c|}
\hline & & \multicolumn{2}{|c|}{$\begin{array}{c}\text { Levene's Test for } \\
\text { Equality of } \\
\text { Variances } \\
\end{array}$} & \multicolumn{7}{|c|}{ t-test for Equality of Means } \\
\hline & & \multirow[t]{2}{*}{$\mathrm{F}$} & \multirow[t]{2}{*}{ Sig. } & \multirow[t]{2}{*}{$\mathrm{T}$} & \multirow[t]{2}{*}{$\mathrm{df}$} & \multirow[t]{2}{*}{$\begin{array}{l}\text { Sig. (2- } \\
\text { tailed) }\end{array}$} & \multirow[t]{2}{*}{$\begin{array}{c}\text { Mean } \\
\text { Difference }\end{array}$} & \multirow[t]{2}{*}{$\begin{array}{l}\text { Std. Error } \\
\text { Difference }\end{array}$} & \multicolumn{2}{|c|}{$\begin{array}{l}95 \% \text { Confidence } \\
\text { Interval of the } \\
\text { Difference }\end{array}$} \\
\hline & & & & & & & & & Lower & Upper \\
\hline \multirow{2}{*}{$\begin{array}{l}\text { Berpi- } \\
\text { kir } \\
\text { Kritis }\end{array}$} & $\begin{array}{c}\text { Equal } \\
\text { variances } \\
\text { assumed }\end{array}$ & 0,620 & 0,435 & $\begin{array}{c}3,27 \\
0\end{array}$ & 45 & 0,002 & 7,445 & 2,277 & 2,860 & 12,030 \\
\hline & $\begin{array}{c}\text { Equal } \\
\text { variances } \\
\text { not } \\
\text { assumed }\end{array}$ & & & $\begin{array}{c}3,21 \\
8\end{array}$ & $\begin{array}{c}39,7 \\
26\end{array}$ & 0,003 & 7,445 & 2,314 & 2,768 & 12,122 \\
\hline
\end{tabular}

Berdasarkan hasil uji $t$ dengan

Berdasarkan simpulan diatas, maka saran

(independent sample $t$ test) diperoleh nilai Sig. (2- diajukan dalam penelian yaitu: (1) Guru tailed) $0.02<0.05$, maka $\mathrm{H}_{0}$ ditolak dan hendaknya bisa melakukan inovasi model $\mathrm{H}_{a}$ diterima atau terdapat perbedaan secara pembelajaran yang sesuai kebutuhan (2) Guru signifikan penggunaan model PBL dan CLIS.

\section{SIMPULAN}

Berdasarkan hasil penelitian tentang Keefektifan Model Pembelajaran Children Learning In Science dengan Problem BasedLearning Terhadap Kemampuan Berpikir Kritis Pembelajaran Tematik Kelas 5 SD Gugus Diponegoro Kedungjati Semester II Tahun Pelajaran 2019/2020, maka dapat disimpulkan bahwa $\mathrm{H}_{\mathrm{a}}$ : Kemampuan berpikir kritis siswa kelas 5 SD Gugus Diponegoro Kedungjati Grobogan menggunakan model pembelajaran Problem Based Learning (PBL) berbeda secara signifikan dibandingkan menggunakan model Children Learning in Science(CLIS). Berdasarkan observasi penggunaan model PBL lebih aktif dibandingkan model CLIS, terlihat bahwa siswa lebih aktif dalam bertanya, menemukan informasi dan berdiskusi. Jika tinggkat berpikir kritis tinggi maka akan berdampak pada hasil belajar yang didapatkan, sehingga dapat dikatakan bahwa model PBL lebih efektif dibandingkan model CLIS terhadap kemampuan berpikir kritis siswa kelas 5 dengan diharapkan dapat mengembangkan berpikir kritis siswa (3) Guru dapat menjadimotivatorserta fasilitator guna membangkitkan minat belajar pada siswa dan mengembangkan potensi siswa itu sendiri. Hasil dari penelitian ini hendaknya dapat ditindaklanjuti pada kasus dan lokasi yang berbeda untuk mengembangkan variabel lain yang dapat mempengaruhi berpikir kritis siswa.

\section{DAFTAR PUSTAKA}

Astutik, P. P. (2016). Integrasi Penguatan Pendidikan Karakter (PPK) dan Higer Order Thinking Skills (HOTS) dalam Pembelajaran Tematik SD. Sinergitas Keluarga, Sekolah, dan Masyarakat dalam Penguatan Pendidikan Karakter, 343-354.

Faiz, Fahruddin. (2012) Pengantar Menuju Berrpikir Kritis. Yogyakarta: Suka Press.

Fajrian, M. O. (2017). Penerapan Model Pembelajaran Children Learning In Science (CLIS) pada Materi Gerak Lurus untuk Meningkatkan Hasil Belajar Siswa Kelas VIII di SMP. UINAR-RANIRY. nilai Sig. (2-tailed) sebesar 0.002 .

Copyright C2020, JRPD, ISSN 2615 - 1723 (Print), ISSN 2615 - 1766 (Online) 
Fisher, A. (2008). Berpikir Kritis . Jakarta: Erlangga.

Nugraheni, S.U (2016). Penerapan Model Pembelajaran Inkuiri Terbimbing Disertai Media Konkrit dalam Peningkatan Keterampilan Berpikir Kritis dan Pemahaman Konsep IPA Tentang Gaya di Kelas V SD. Kalam Cendekia, Vol. 4, No. 5.1, hlm 576-583

Purwati, R. (2016). Analisis Kemampuan Berpikir Kritis Siswa dalam Menyelesaikan Masalah Persamaan Kuadrat Pada Pembelajaranmodel Creative Problem Solving. Kadikma, Vol 7 No 1, 84-93.

Rohmatin, D. N. (2014). Penerapan Model Pembelajaran Pengajuan dan Pemecahan Masalah untuk Meningkatkan Kemampuan Berpikir Kritis Siswa. Gamatika Vol. 5 No. 1, 1-7.

Rosana, L. N. (2014). Pengaruh Metode Pembelajaran dan Kemampuan Berpikir Kritis Terhadap Hasil Belajar Sejarah Siswa. Jurnal Pendidikan Sejarah Vol 3 No 1, 34-44.

Sari, D. D. (2012). Penerapan Model Problem Based Learning(PBL) untuk Meningkatkan Kemampuan Berpikir Kritis Peserta Didik Pada Pembelajaran IPA Kelas VIII SMP Negeri 5 Sleman. Yogyakarta: Universitas Negeri Yogyakarta.

Setiawan, A. R. (2018). Penerapan Pendekatan Saintifik untuk Melatih Literasi Saintifik dalam Domain Kompetensi pada Topik Gerak Lurus di Sekolah Menengah Pertama. Prosiding Seminar Nasional Fisika (SINAFI), 7-13.

Wardani, T.W (2015). Keefektifan Model (CLIS) Children Learning In Science Terhadap Aktifitas dan Hasil Belajar Energi Siswa Kelas III SDN 01 Cikawang. Semarang: Universitas Negeri Semarang

Copyright (C2020, JRPD, ISSN 2615 - 1723 (Print), ISSN 2615 - 1766 (Online) Indonesia dan Kesiapannya dalam Menghadapi Masyarakat Ekonomi Asia (MEA). Cendekia Vol. 13 No. 2, 294-307.

Zubaidah, S. (2016). Keterampilan Abad Ke21: Keterampilan yang Diajarkan Melalui Pembelajaran. Khatulistiwa Sintang, 1-17. 